\title{
Drug-drug interactions of tacrolimus
}

\author{
Nemanja K. Rančić ${ }^{1}$, Neven N. Vavićz, Aleksandra M. Kovačević ${ }^{1}$, \\ Momir M. Mikov³, Viktorija M. Dragojević - Simić \\ ${ }^{1}$ Centre for Clinical Pharmacology, Medical Faculty of Military Medical Academy, University of \\ Defence, Belgrade, Serbia \\ ${ }^{2}$ Centre for Transplantation of Solid Organs, Military Medical Academy, Belgrade, Serbia \\ ${ }^{3}$ Department of Pharmacology, Toxicology and Clinical Pharmacology, Medical Faculty, \\ University of Novi Sad, Serbia
}

\section{SUMMARY}

Introduction: Tacrolimus, potent immunosupressive drug, has large inter- and intraindividual pharmacokinetic variability.

The aim: The aim of this current topic is to describe the importance of tacrolimus drug-drug interactions.

Pharmacokinetic interactions between tacrolimus and other drugs: Concerning the fact that it is also a medicine with the narrow therapeutic range, its interactions with other drugs mediated by both P-glycoprotein and CYP3A enzymes are potentially very important.

Conclusion: Interactions between tacrolimus and other drugs leading to overexposure to tacrolimus is connected with significant toxicity, while the subtherapeutic blood concentrations increase the probability of transplanted organ rejection.

Keywords: tacrolimus, P-glycoprotein, CYP3A enzymes, drug-drug interactions

\section{INTRODUCTION}

Tacrolimus is a macrolide immunosuppressant that is used to prevent organ rejection in patients with liver, kidney or heart grafts. It is a lipophilic drug with a narrow therapeutic window. Due to its physicochemical characteristics it is a subject of intensive metabolism and has highly variable absorbtion and, as a result of that, its main characteristics are variable pharmacokinetics [1-4]. However, due to its potency, tacrolimus is widely used to prevent allograft rejection in the patients with transplanted organs or tissues [5]. Due to all these facts, tacrolimus is the most common research drug subject in the transplantation area.

\section{THE AIM}

The aim of this current topic is to describe the importance of tacrolimus drug-drug interactions, as well as to present short review of such interactions.

\section{PHARMACOKINETIC INTERACTIONS BETWEEN TACROLIMUS AND OTHER DRUGS}

Tacrolimus absorption from the human gastrointestinal tract shows great variability. In some patients it is rapidly absorbed after oral administration (maximal blood concentration can be achieved in approximately 1 to 2 hours), while in others absorption time can be slower or even delayed.

The bioavailability of tacrolimus is low (about 20\%) due to its extensive presystemic metabolism, but may vary between 4 to $93 \%[6,7]$. It is a substrate of P-glycoprotein 
Table 1. Drugs that interact with tacrolimus through P-glycoprotein efflux pump efflux pump, which is one of the drug transporters that determine a range of its uptake and efflux [8-11].

P-glycoprotein functions as a transmembrane efflux pump, pumping substrates from the intracellular to extracellular space. This pump is presented in the intestinal epithelium, renal tubules epithelium, hepatocytes, blood-brain-barrier and placenta [12]. Therefore, tacrolimus bioavailability is largely determined by its pumping back into the intestinal lumen mediated by this efflux transporter. P-glycoprotein inductors and inhibitors interact with tacrolimus through this pump (Table 1) [11, 13]. Some drugs, substrate of P-glycoprotein, may occupy active places of this pump, which may lead to higher tacrolimus absorption and bioavailability $[9,11]$. On the other hand, the inhibition or induction of P-glycoprotin may produce the increased or decreased tacrolimus blood concentration, respectively.

\begin{tabular}{|ccc}
\hline Inhibitors & P-glycoprotein & \\
\hline azithromycin & Inducers & Substrates \\
amiodarone & avasimibe & azithromycin \\
conivaptan & ambrisentan & actinomycin \\
\hline verapamil & dabigatran & vinblastine \\
\hline diltiazem & everolimus & vincristine \\
\hline dronedarone & imatinib & dexamethasone \\
\hline erythromycin & carbamazepine & digoxin \\
\hline indinavir & ranolazine & doxorubicin \\
\hline itraconazole & ritonavir & etoposide \\
\hline captopril & rifampin & colchicine \\
\hline carvedilol & rifampicin & cortisol \\
\hline quinidine & sirolimus & lovastatin \\
\hline ketoconazole & talinolol & paclitaxel \\
\hline clarithromycin & tipranavir & terfenadine \\
conivaptan & topotecan & fexofenadine \\
lopinavir & phenytoin & \\
ranolazine & & \\
ritonavir & & \\
felodipine & & \\
\hline cyclosporine & & \\
\hline
\end{tabular}

lead to the increased probability of organ rejection $[22,25,26]$.

The clinical significance of the described interactions is very important. For example, interactions between tacrolimus and proton pump inhibitors (omeprazole and
Tacrolimus is metabolized in the liver by cytohrome P450 (CYP) [7]. It is a substrate of both CYP3A4 and CYP3A5 enzymes. Gene polymorphisms of both CYP3A4 and CYP3A5 enzymes are significant factor which contributes to its highly variable bioavailability [1418]. Therefore, tacrolimus large inter- and intra-individual pharmacokinetic variability could be at least partially explained by the genetic polymorphism of CYP3A genes.

Drug interactions with tacrolimus mediated by CYP3A enzymes, affecting its concentrations in blood are presented in Table 2 [19-24]. CYP3A enzyme system inhibitors may lead to the increased tacrolimus blood concentrations, while its inducers may reduce them. Substrates of CYP3A enzyme system probably occupy them leading to increased tacrolimus blood concentrations. Overexposure to aforementioned substrates can results in significant tacrolimus toxicity, while the subtherapeutic blood concentrations probably 


\begin{tabular}{|c|c|c|c|c|}
\hline \multicolumn{5}{|c|}{ CYP3A } \\
\hline \multicolumn{2}{|c|}{ Inhibitors } & \multicolumn{2}{|c|}{ Substrates } & Inducers \\
\hline bromocriptine & macrolides & alprazolam & lidocaine & aluminium hydroxide \\
\hline verapamil & methylprednisolone & alfentanil & lovastatin & dexamethasone \\
\hline voriconazole & metoclopramide & amiodarone & loratadine & ethosuximide \\
\hline glibenclamide & metronidazole & amlodipine & nevirapine & isoniazid \\
\hline grapefruit & midazolam & atorvastatin & nicardipine & carbamazepine \\
\hline dalfopristin & midecamycin & warfarin & nifedipine & magnesium oxide \\
\hline danazol & miconazole & venlafaxine & omeprazole & methylprednisolone \\
\hline delavirdine & nelfinavir & vinblastine & paclitaxel & nevirapine \\
\hline diltiazem & nefazodone & dabigatran & progesterone & orlistat \\
\hline erythromycin & nicardipine & dantrolene & propafenone & prednisone \\
\hline etinilestradiol & prednisolone & dapsone & sertraline & rifabutin \\
\hline zafirlukast & prednisone & diazepam & simvastatin & rifampicin \\
\hline indinavir & progesterone & disopyramide & tamoxifen & sirolimus \\
\hline itraconazole & ritonavir & enalapril & testosterone & sodium bicarbonate \\
\hline quinupristin & saquinavir & estradiol & triazolam & sulfapyridine \\
\hline ketoconazole & troleandomycin & estrogen & felodipine & phenylbutazone \\
\hline clarithromycin & fluvoxamine & etoposide & flutamide & phenytoin \\
\hline clotrimazole & fluconazole & zolpidem & chlorpromazine & phenobarbital \\
\hline cortisol & fluoxetine & quinidine & cyclophosphamide & \\
\hline lansoprazole & chloramphenicol & clonazepam & cilostazol & \\
\hline levofloxacin & cyclosporine & cocaine & cisapride & \\
\hline lopinavir & cimetidine & cortisol & & \\
\hline
\end{tabular}

Table 2. Drugs that interact with tacrolimus through CYP3A enzymes for CYP3A4 enzymes and compete each other for these enzymes as well as for P-glycoprotein, drug interactions should be anticipated when these drugs are administrated simultaneously. Therefore, combining these drugs leads to increased tacrolimus blood concentrations, since, as it was mentioned, omeprazole and lansoprazole are inhibitors and/or substrates of CYP3A4 enzymes and P-glycoprotein efflux pump [27-30].

On the other hand, calcium channel blockers (diltiazem, nifedipine, amlodipine) are potent inhibitors and/or substrates of CYP3A4 and CYP3A5 enzymes, as well as of Pglycoprotein transporter, and they can rapidly increase tacrolimus blood concentrations [31]. Since calcium channel blockers decrease the clearance of tacrolimus by partial competative inhibiton of metabolic pathway, it leads to a significantly elevated tacrolimus blood concentrations $[32,33]$.

\section{CONCLUSION}

Tacrolimus drug-drug interactions mediated by both P-glycoprotein and CYP3A enzymes are potentially very important, concerning the narrow therapeutic range of this immunosuppressant and variable pharmacokinetics. Therefore, relativelly small alterations in tacrolimus bioavailability and its metabolism, as a whole, may lead to the significant increase or decrease of its blood level. Interactions with other drugs leading to overexposure of tacrolimus is connected with significant toxicity, while the subtherapeutic blood concentrations lead to the increased probability of transplanted organ rejection.

Understanding the fundamental principles of tacrolimus drug-drug interactions could contribute to better transplant patients pharmacotherapy, especially concerning the fact that it is a long-term and expensive treatment associated with transplant rejection risk.

\section{ACKNOWLEDGMENTS}

The authors would like to express their gratitude to the Ministry of Science and Education 
of the Republic of Serbia for Grant numbers 175014 and 175093 , out of which this research project was partially financed.

\section{REFERENCES}

1. Velickovic-Radovanovic R, Mikov M, Catic-Djordjevic A, Stefanovic N, Mitic B, Paunovic G, Cvetkovic T. Gender-dependent predictable pharmacokinetic method for tacrolimus exposure monitoring in kidney transplant patients. Eur J Drug Metab Pharmacokinet. 2015;40(1):95-102.

2. Hane K, Fujioka M, Namiki Y, Kitagawa T, Kihara N, Shimatani K, Yasuda T. Physico-chemical properties of (-)-(1R,9S,12S,13R,14S,17R, 18E, 21 $S, 23 S, 24 R, 27 R)$-17-allyl-1,14-dihydroxy-12-[(E)2-[(1R,3R,4R)-4-hydroxy-3-methoxycyclohexyl]1-methylvinyl]-23,25-dimethoxy-13,19,21,27-tetramethyl-11,28-dioxa-4-azatricyclo[22.3.1.04,9] octacos-18-ene-2,3,10,16-tetroen hydrate (FK506). lyakuhin Kenkyu 1992;23:33-43.

3. Kuypers DR, Claes K, Evenepoel P, Maes B, Vanrenterghem $Y$. The rate of gastric emptying determines the timing but not the extent of oral tacrolimus absorption: simultaneous measurement of drug exposure and gastric emptying by carbon-14octanoic acid breath test in stable renal allograft recipients. Drug Metab Dispos 2004;32(12):1421-5.

4. Niioka T, Kagaya $H$, Miura M, Numakura K, Saito M, Inoue T, Habuchi T, Satoh S. Pharmaceutical and genetic determinants for interindividual differences of tacrolimus bioavailability in renal transplant recipients. Eur J Clin Pharmacol 2013;69(9):1659-65.

5. Bowman LJ, Brennan DC. The role of tacrolimus in renal transplantation. Expert Opin Pharmacother 2008;9(4):635-43.

6. Wallemacq PE, Verbeeck RK. Comparative clinical pharmacokinetics of tacrolimus in paediatric and adult patients. Clin Pharmacokinet 2001;40(4):28395.

7. Iwasaki K. Metabolism of tacrolimus (FK506) and recent topics in clinical pharmacokinetics. Drug Metab Pharmacokinet 2007;22(5):328-35.

8. Jeong $\mathrm{H}$, Chiou WL. Role of P-glycoprotein in the hepatic metabolism of tacrolimus. Xenobiotica 2006;36(1):1-13.

9. Finch A, Pillans P. P-glycoprotein and its role in drug-drug interactions. Australian prescriber 2014;37(4):137-9.

10. König J, Müller F, Fromm MF. Transporters and drug-drug interactions: important determinants of drug disposition and effects. Pharmacol Rev 2013;65(3):944-66.

11. Rendić S, Medić-Šarić M. Metabolizam lijekova i odabranih ksenobiotika. Zagreb: Medicinska naklada; 2013.

12. Saeki T, Ueda K, Tanigawara Y, Hori R, Komano
T. Human P-glycoprotein transports cyclosporin A and FK506. J Biol Chem 1993;268:6077-80.

13. U.S. Food and Drug Administration. Protecting and Promoting Your Health. Drug Development and Drug Interactions: Table of Substrates, Inhibitors and Inducers. Last Updated: 10/27/2014. Available from: http://www.fda.gov/Drugs/DevelopmentApprovalProcess/DevelopmentResources/DrugInteractionsLabeling/ucm093664.htm (cited 23.10.2015.).

14. Staatz CE, Tett SE. Clinical pharmacokinetics and pharmacodynamics of tacrolimus in solid organ transplantation. Clin Pharmacokinet 2004;43(10):623-53.

15. Stefanović N, Cvetković T, VeličkovićRadovanović R, Jevtović-Stoimenov T, Stojanović D, Živković N. Significance of CYP3A5 gene polymorphism in Serbian renal transplant patients. Acta Medica Medianae 2013;52(1):33-7.

16. Shiraga $T$, Niwa T, Teramura $Y$, Kagayama A, Tsutsui M, Ohno Y, Iwasaki K. Oxidative metabolism of tacrolimus and its metabolite by human cytochrome P450 3A subfamily. Xenobio Metab Dispos 1999;14:277-385.

17. Li Y, Yan L, Shi Y, Bai Y, Tang J, Wang L. CYP3A5 and $A B C B 1$ genotype influence tacrolimus and sirolimus pharmacokinetics in renal transplant recipients. Springerplus 2015;4:637. doi: 10.1186/ s40064-015-1425-5.

18. Shi WL, Tang HL, Zhai SD. Effects of the CYP3A4*1B Genetic Polymorphism on the Pharmacokinetics of Tacrolimus in Adult Renal Transplant Recipients: A Meta-Analysis. PLoS One 2015;10(6):e0127995. doi: 10.1371 /journal.pone. 0127995 .

19. van Maarseveen EM, Rogers CC, Trofe-Clark J, van Zuilen AD, Mudrikova T. Drug-drug interactions between antiretroviral and immunosuppressive agents in HIV-infected patients after solid organ transplantation: a review. AIDS Patient Care STDS 2012;26(10):568-81.

20. Christians U, Jacobsen W, Benet LZ, Lampen A. Mechanisms of clinically relevant drug interactions associated with tacrolimus. Clin Pharmacokinet 2002;41(11):813-51.

21. Rancic N, Dragojevic-Simic V, Vavic N, Kovacevic A, Segrt Z, Draskovic-Pavlovic B, Mikov M. Tacrolimus concentration/dose ratio as a therapeutic drug monitoring strategy: the influence of gender and comedication. Vojnosanit pregl 2015;72(9):813-22.

22. Vavic N, Rancic N, Dragojevic-Simic V, Draskovic-Pavlovic B, Bokonjic D, Ignjatovic L, Mikov M. The influence of comedication on tacrolimus blood concentration in patients subjected to kidney transplantation: a retrospective study. Eur J Drug Metab Pharmacokinet 2014;39(4):243-53.

23. Gabardi S, Olyaei JA. Solid organ transplantation. In: Chisholm-Burns MA, Schwinghammer TL, Wells BG, Malone PM, Kolesar JM, DiPiro JT, eds. Pharmacotherapy Principles and Practice. New 
York: McGraw Hills Companies, Inc., 2010:939-64.

24. Sweetman SC, ed. Martindale: The Complete Drug Reference 37. [CD-ROM] London: Pharmaceutical Press; 2011.

25. Vavić N, Rančić N, Cikota-Aleksić B, Magić Z, Cimeša $J$, Obrenčević $K$, Radojević $M$, Mikov $M$, Dragojević-Simić V. The distribution of genetic polymorphism of CYP3A5, CYP3A4 and $A B C B 1$ in patients subjected to renal transplantation. Vojnosanit pregl 2015; In press.

26. Rančić N. Assessment of tacrolimus concentration/dose ratio as a parameter for the therapeutic monitoring in the patients subjected to kidney transplantation. [Ph.D. Thesis] Kragujevac: Faculty of Medical Sciences; 2015.

27. Takahashi K, Yano I, Fukuhara Y, Katsura T, Takahashi T, Ito N, Yamamoto S, Ogawa O, Inui K. Distinct Effects of Omeprazole and Rabeprazole on the Tacrolimus Blood Concentration in a Kidney Transplant Recipient. Drug Metab Pharmacokinet 2007;22(6):441-4

28. Isoda K, Takeuchi T, Kotani T, Hirano-Kuwata S, Shoda T, Hata K, Yoshida S, Makino S, Hanafusa T. The proton pump inhibitor lansoprazole, but not rabeprazole, the increased blood concentrations of calcineurin inhibitors in Japanese patients with connective tissue diseases. Intern Med 2014;53(13):1413-8.

29. Hosohata K, Masuda S, Ogura Y, Oike F, Takada $\mathrm{Y}$, Katsura T, Uemoto S, Inui K. Interaction between tacrolimus and lansoprazole, but not rabeprazole in living-donor liver transplant patients with defects of CYP2C19 and CYP3A5. Drug Metab Pharmacokinet 2008;23(2):134-8.

30. Miura $M$, Inoue K, Kagaya $H$, Satoh $S$, Tada $H$, Sagae Y, Habuchi T, Suzuki T. Influence of rabeprazole and lansoprazole on the pharmacokinetics of tacrolimus in relation to CYP2C19, CYP3A5 and MDR1 polymorphisms in renal transplant recipients. Biopharm Drug Dispos 2007;28(4):167-75.

31. Li JL, Wang XD, Chen SY, Liu LS, Fu Q, Chen X, Teng LC, Wang CX, Huang M. Effects of diltiazem on pharmacokinetics of tacrolimus in relation to CYP3A5 genotype status in renal recipients: from retrospective to prospective. Pharmacogenomics J 2011;11(4):300-6.

32. Leroy S, Fargue S, Bensman A, Deschênes $G$, Jacqz-Aigrain E, Ulinski T. Tacrolimus adverse events in transplant recipients with diarrhoea or calcium channel blockers: Systematic review. Medical Case Studies 2011;2(7):58-68.

33. Zhao W, Baudouin V, Fakhoury M, Storme T, Deschênes $G$, Jacqz-Aigrain $E$. Pharmacokinetic interaction between tacrolimus and amlodipine in a renal transplant child. Transplantation 2012;93(7):e2930. 


\section{Interakcije takrolimusa sa drugim lekovima}

Nemanja K. Rančić ${ }^{1}$, Neven N. Vavić , Aleksandra M. Kovačević1, Momir M. Mikov³, Viktorija M. Dragojević-Simić ${ }^{1}$

${ }^{1}$ Centar za kliničku farmakologiju, Medicinski fakultet Vojnomedicinske akademije, Univerzitet Odbrane, Beograd, Srbija

${ }^{2}$ Centar za transplantaciju solidnih organa, Vojnomedicinska akademija, Beograd, Srbija

${ }^{3}$ Katedra za farmakologiju, toksikologiju i kliničku farmakologiju, Medicinski fakultet,

Univerzitet u Novom Sadu, Srbija

\section{KRATAK SADRŽAJ}

Uvod: Takrolimus, potentni imunosupresivni lek, ima veliku inter i intra-individualnu farmakokinetsku varijabilnost.

Cilj: Cilj ove aktuelne teme jeste da opiše značajne interakcije takrolimusa sa drugim lekovima.

Farmakokinetske interakcije između takrolimusa i drugih lekova: S obzirom na činjenicu da je ovo lek sa malom terapijskom širinom, interakcije takrolimusa sa drugim lekovima preko P-glikoproteina i CYP3A enzima su potencijalno veoma značajne.

Zaključak: Interakcije takrolimusa sa određenim lekovima vode ili ka preteranom izlaganju takrolimusu što je povezano sa značajnom toksičnošću, ili ka koncentracijama leka u krvi ispod minimalnih željenih što može dovesti do odbacivanja transplantiranog organa.

Ključne reči: takrolimus, P-glikoprotein, CYP3A enzimi, interakcije lekova 